\title{
Vegetation response to increasing stocking rate under rotational stocking
}

\author{
C.A. TAYLOR, JR., M.H. RALPHS, AND M.M. KOTHMANN
}

Authors are experiment station superintendent, Texas A\&M University Research Station, Sonora, Tex. 76950; rangeland scientist, USDA/ARS Poisonous Plant Lab, 1150 E 1400 N, Logan, Ut. 84341; and professor, Texas A \&M University, College Station, Tex.

Abstract

This 10-year study was designed to evaluate vegetation response to increasing stocking rates under rotational stocking (3 days graze, 51 days rest) and long-term rest. The 4 stocking rate treatments ranged from the recommended rate for moderate continuous grazing to 2.7 times the recommended rate. Common curly-mesquite [Hilaria belangeri (Steud.) Nash] increased (P 0.05 ) in all grazed treatments and decreased in the livestock exclosure. Sideoats grama [Bouteloua curtipendula (Michx.) Torr.] along with other midgrasses decreased $(P=0.07)$ in all grazed treatments and increased in the livestock exclosure. Because the midgrasses were palatable species and not abundant, they were defoliated too intensively and too frequently. Rotational stocking was not able to sustain initial species composition at any of the stocking rates tested.

Key Words: botanical composition, native range, livestock grazing, grazing management, rotational grazing

Many different kinds of stocking methods have been examined on rangelands (Kothmann 1980, Heitschmidt and Taylor 1991, Holechek et al. 1989). During the past 2 decades, considerable attention has been given to rotational stocking methods that utilize recurring periods of stocking and rest among 2 or more paddocks in a grazing management unit. Rotational stocking methods have been recommended as a means to enhance vegetation, livestock, and wildlife production. Theoretically, benefits from rotational stocking result from control of selective grazing. Rotational stocking has been intensively studied on the Texas A\&M University Research Station at Sonora, Tex., to determine its effects on rangeland hydrology (Thurow et al. 1987, 1988, and Warren et al. 1986a, 1986b), livestock production, and vegetation changes (Ralphs et al. 1990, Taylor et al. 1980, 1993a, 1993b, 1993c). The objective of this study was to determine the effects of stocking rate under rotational stocking on species composition and frequency of the primary herbaceous vegetation components.

Manuscript accepted 5 Oct. 1996.
Methods

A grazing study initiated in 1980 was continued until 1991. Ralphs et al. (1990) reported results from the first 5 years of this study. This paper analyzes the combined 10 -year vegetation response data and compares it to vegetation changes in an adjacent ungrazed livestock exclosure.

The study was conducted on the Texas Agricultural Experiment Station located near Sonora, Tex. $\left(31^{\circ} \mathrm{N} ; 100^{\circ} \mathrm{W}\right)$. It lies in the Edwards Plateau region of Texas (Gould 1975) with an average elevation of $735 \mathrm{M}$. Precipitation is highly variable both between and within years. The average annual precipitation is $577 \mathrm{~mm}$.

Soils were Tarrant stony clay, 8 to $15 \mathrm{~cm}$ deep, and Tarrant silty clay, 15 to $25 \mathrm{~cm}$ deep (members of the clayey-skeletal, montmorillonitic, thermic family of Lithic Haplustalls). Range site classification was Low Stony Hills (SCS 1972).

An 8.5-ha pasture was subdivided into 2 blocks of 4 pastures each for the grazed treatments (Table 1) with an additional pasture for a livestock exclosure. Four stocking rate treatments were randomly applied to the 4 pastures in each block. Stocking rates in block 2 were $20 \%$ greater than those in block 1 because there was a higher proportion of the deeper Tarrant silty clay soils which were more productive than the shallow Tarrant stony clay soil. Stocking rates were $1.38,2.05,2.64$, and $3.46 \mathrm{AUM} / \mathrm{ha}$ for block 1, and 1.67, 2.52,3.23, and 4.21 AUM/ha for block 2 . These represented $1,1.5,2$, and 2.5 times the recommended stocking rate for the respective sites (Merrill and Young 1954). Experimental procedures for livestock grazing and vegetation sampling followed those described by Ralphs et al. (1990). Herbaceous species from 50 quadrats were sampled in each pasture during September 1980, April 1985, and May 1991 using the two-step sampling technique described by Anderson and Kothmann (1982). Units of foliar cover were visually estimated using a $1 \times 0.25-\mathrm{m}$ frame sectioned with a $6.25-\mathrm{cm}$ grid. Ten of the plots were clipped and species were separated and dried to determine weight per unit of cover, multiplied by the number of cover units of each plant species. Species composition by weight were calculated for the following 6 selected categories of herbaceous vegetation: (1) common curly-mesquite [Hilaria belangeri (Steud.) Nash], (2) other short grasses (red grama [Bouteloua trifida Thurb.], hairy grama [ $B$. hirsuta Lag.], and hairy tridens 
Table 1. Study design, area in pastures and stocking rate treatments. Pasture sizes in Rep 2 were decreased 20\% to increase stocking rates due to deeper, more productive soils.

\begin{tabular}{|c|c|c|c|c|c|}
\hline \multicolumn{3}{|c|}{$\operatorname{Rep} 1$} & \multicolumn{3}{|c|}{ Rep 2} \\
\hline \multirow[t]{2}{*}{$\begin{array}{l}\text { Stocking rate } \\
\text { treatment }^{1}\end{array}$} & \multicolumn{2}{|c|}{$\frac{\text { Stocking rates }}{\text { Area }}$} & $\begin{array}{l}\text { Stocking rate } \\
\text { treatment }\end{array}$ & \multicolumn{2}{|c|}{$\frac{\text { Stocking rates }}{\text { Area }}$} \\
\hline & (ha) & (AUM/ha) & & (ha) & (AUM/ha) \\
\hline $1.0 \mathrm{x}$ & 1.68 & 1.19 & $1.0 \mathrm{x}$ & 1.20 & 1.67 \\
\hline $1.5 \mathrm{x}$ & 0.98 & 2.05 & $1.5 \mathrm{x}$ & 0.79 & 2.52 \\
\hline $2.0 x$ & 0.75 & 2.64 & $2.0 x$ & 0.62 & 3.23 \\
\hline $2.5 x$ & 0.58 & 3.46 & $2.5 x$ & 0.47 & 4.21 \\
\hline
\end{tabular}

${ }^{1}$ Increase in stocking rate compared to the recommended rate.

[Erioneuron pilosum (Buckl.) Nash], (3) threeawns (Wright threeawn [Artistida wrightii Nash] and purple threeawn [A. purpurea Nutt.]), (4) sideoats grama [B. curtipendula (Michx.) Torr.], (5) other midgrasses (fall witchgrass [Digitaria cognata (Schult.) Pilger), Merrill bluestem [Bothriochloa edwardsiana (Gould) L.R. Parodi], vine mesquite [Panicum obtusum Kunth in H.B.K.], and King Ranch bluestem [B. ischaemum (L.) Keng var. songarica (Fisch. \& Mey.) Celarier \& Harlan], and (6) cool-season grasses (Texas wintergrass [Stipa leucotricha Trin. \& Rupr.], sedge [Carex spp.], and rescuegrass [Bromus unioloides Kunth in H.B.K.].

Composition of species in the standing crop was calculated by dividing the standing crop of individual grass species by the total grass standing crop. A split-plot ANOVA was used to compare stocking rate treatments over time. Stocking rate was the whole plot, year was the split plot and pastures were experimental units. The exclosure data were not included in this analysis. Data from all stocking rate treatments were pooled and compared to the ungrazed treatment by a t-test. If the variance of the treatment means were found to be significantly different $(P<0.05)$, then an unpaired t-test for unequal variances was used, otherwise a test for equal variances was applied (SAS 1988).

\section{Results and Discussion}

\section{Common Curly-mesquite}

In 1980 , common curly-mesquite averaged $26 \%$ of total grass standing crop by weight, ranging from $20 \%$ at the $2 x$ stocking rate to $32 \%$ at the $1 x$ stocking rate and $42 \%$ in the livestock exclosure (Table 2). In 1985, curly-mesquite averaged $35 \%$, ranging from $33 \%$ at the $1 \mathrm{x}$ stocking rate to $37 \%$ at the $2.5 \mathrm{x}$ stocking rate. The livestock exclosure was not sampled in 1985. By 1991, curly-mesquite averaged $77 \%$ under grazing treatments, ranging from $70 \%$ at the $1 \mathrm{x}$ stocking rate to $79 \%$ at the $2 \mathrm{x}$ and $2.5 \mathrm{x}$ stocking rates but dropped to less than $1 \%$ of the grass standing crop in the livestock exclosure. The change in percent composition of curly-mesquite differed $(P<0.05)$ for the grazed treatments compared to the non-grazed treatments. Curly-mesquite increased more on the grazed pastures in the last 5 years $(42 \%)$ than in the first 5 years $(9 \%)(P=0.01)$.

This non-linear increase of curly-mesquite from 1980 to 1991 is difficult to explain. Variable precipitation could be one factor that affected curly-mesquite. Precipitation was favorable for the first 5 years of the study ( $98 \%$ of average with $68 \%$ coming within the growing season). Precipitation was greater for the last 5 year period ( $101 \%$ of average with $76 \%$ coming during the growing season). An extremely cold period occurred during December of 1983, which resulted in the die-off of large amounts of warm season grasses (mostly curly-mesquite; Fuhlendorf 1996). When curly-mesquite died in the exclosure, it opened a niche for the midgrasses to increase. However in the grazed treatments, midgrasses apparently were not able to exploit the reduced competition from curly-mesquite and it reestablished dominance. This could have been a greater factor influencing the response of curly-mesquite than precipitation.

An increase in curly-mesquite associated with increasing grazing pressure is a common vegetative response on central Texas rangelands (Merrill and Young 1959, Smeins and Merrill 1988). Curly-mesquite is a low, tufted, stoloniferous perennial with erect flowering culms which originate from small vegetative clumps. It has the ability to persist and even maintain dominance within grazed grassland communities because of its abilities to reproduce prolifically by seed and stolons (Smeins and Merrill 1988, Kinucan 1987). The response of curly-mesquite in this study is very similar to that under heavy continuous yearlong grazing. The authors predicted this response in their earlier conclusions (Ralphs et al. 1990).

The significant decrease in curly-mesquite in the exclosure is similar to the response of buffalograss [Buchloe dactyloides (Nutt.) Engelm.] in grazing exclosures in the Rolling Plains of

Table 2. Means and standard errors for species composition (percent based on grass standing crop) of major grasses for 1980, 1985, and 1991 in an exclosure and at 4 stocking rates (NS = not sampled).

\begin{tabular}{|c|c|c|c|c|}
\hline \multirow[t]{2}{*}{ Species } & \multirow{2}{*}{$\begin{array}{c}\text { Stocking } \\
\text { Rate }\end{array}$} & \multicolumn{3}{|c|}{ Year } \\
\hline & & 1980 & 1985 & 1991 \\
\hline & $\ldots-$. & $\cdots-\cdots$ & $-(\%)---$ & $-\ldots$ \\
\hline HIВЕ ${ }^{2}$ & $1.0 \mathrm{x}$ & $32 \pm 2^{\mathfrak{a}}$ & $33 \pm 10^{a b}$ & $70 \pm 17^{b}$ \\
\hline HIBE & $1.5 x$ & $25 \pm 5^{2}$ & $40 \pm 10^{\mathrm{ab}}$ & $79 \pm 25^{b}$ \\
\hline HIBE & $2.0 \mathrm{x}$ & $20 \pm 2^{a}$ & $32 \pm 1^{\mathrm{ab}}$ & $78 \pm 20^{b}$ \\
\hline HIBE & $2.5 x$ & $29 \pm 12^{a}$ & $37 \pm 10^{\mathrm{ab}}$ & $79 \pm 20^{b}$ \\
\hline HIBE & $0.0 \mathrm{x}$ & $42 \pm 23^{a}$ & NS & $1 \pm 1^{b}$ \\
\hline SHGR $^{3}$ & $1.0 \mathrm{x}$ & $32 \pm 2^{\mathrm{ab}}$ & $36 \pm 9^{a}$ & $10 \pm 7^{b}$ \\
\hline SHGR & $1.5 x$ & $25 \pm 5^{\mathrm{ab}}$ & $43 \pm 11^{a}$ & $4 \pm 2^{b}$ \\
\hline SHGR & $2.0 x$ & $25 \pm 2^{b}$ & $46 \pm 3^{a}$ & $8 \pm 5^{c}$ \\
\hline SHGR & $2.5 x$ & $32 \pm 8^{\mathrm{ab}}$ & $42 \pm 6^{a}$ & $11 \pm 8^{b}$ \\
\hline SHGR & $0.0 x$ & $14 \pm 10^{a}$ & NS & $2 \pm 1^{a}$ \\
\hline $\mathrm{ARS}^{4}$ & $1.0 \mathrm{x}$ & $9 \pm 1^{a}$ & $8 \pm 3^{8}$ & $12 \pm 8^{a}$ \\
\hline ARS & $1.5 x$ & $13 \pm 6^{a}$ & $3 \pm 1^{\mathrm{a}}$ & $10 \pm 9^{a}$ \\
\hline ARS & $2.0 \mathrm{x}$ & $17 \pm 4^{2}$ & $4 \pm 1^{a}$ & $2 \pm 1^{a}$ \\
\hline ARS & $2.5 x$ & $8 \pm 3^{n}$ & $4 \pm 1^{n}$ & $5 \pm 3^{a}$ \\
\hline ARS & $0.0 \mathrm{x}$ & $19 \pm 4^{a}$ & NS & $18 \pm 8^{a}$ \\
\hline $\mathrm{BOCU}^{5}$ & $1.0 x$ & $5 \pm 1^{a}$ & $4 \pm 1^{2}$ & $1 \pm 1^{b}$ \\
\hline BOCU & $1.5 x$ & $5 \pm 1^{2}$ & $2 \pm 1^{b}$ & $2 \pm 1^{b}$ \\
\hline BOCU & $2.0 \mathrm{x}$ & $9 \pm 2^{\mathrm{a}}$ & $3 \pm 2^{a b}$ & $1 \pm 1^{b}$ \\
\hline BOCU & $2.5 x$ & $4 \pm 1^{a}$ & $1 \pm 1^{b}$ & $1 \pm 1^{b}$ \\
\hline BOCU & $0.0 \mathrm{x}$ & $15 \pm 7^{\mathrm{a}}$ & NS & $25 \pm 1^{b}$ \\
\hline MIDGR $^{6}$ & $1.0 \mathrm{x}$ & $14 \pm 1^{2}$ & $14 \pm 3^{a}$ & $1 \pm 1^{b}$ \\
\hline MIDGR & $1.5 x$ & $20 \pm 5^{a}$ & $7 \pm 2^{\mathrm{ab}}$ & $1 \pm 1^{b}$ \\
\hline MIDGR & $2.0 \mathrm{x}$ & $15 \pm 2^{a}$ & $11 \pm 3^{a}$ & $9 \pm 3^{a}$ \\
\hline MIDGR & $2.5 x$ & $16 \pm 2^{a}$ & $9 \pm 4^{\mathrm{ab}}$ & $1 \pm 1^{b}$ \\
\hline MIDGR & $0.0 \mathrm{x}$ & $3 \pm 2^{a}$ & NS & $53 \pm 10^{b}$ \\
\hline $\mathrm{CSGR}^{7}$ & $1.0 x$ & $8 \pm 3^{a}$ & $7 \pm 1^{a}$ & $14 \pm 9^{a}$ \\
\hline CSGR & $1.5 \mathrm{x}$ & $13 \pm 2^{a}$ & $6 \pm 2^{a b}$ & $1 \pm 1^{b}$ \\
\hline CSGR & $2.0 \mathrm{x}$ & $14 \pm 1^{a}$ & $5 \pm 4^{\mathrm{ab}}$ & $2 \pm 1^{b}$ \\
\hline CSGR & $2.5 x$ & $10 \pm 2^{a}$ & $8 \pm 6^{a b}$ & $3 \pm 1^{b}$ \\
\hline CSGR & $0.0 \mathrm{x}$ & $8 \pm 4^{2}$ & NS & $2 \pm 2^{a}$ \\
\hline
\end{tabular}

Increase in stocking rate compared to the recommended rate.

${ }_{3}^{2}$ HIBE = Common curly-mesquite.

${ }^{3}$ SHGR $=$ Short grasses.

${ }^{4}$ ARS $=$ Throeawn.

5 BOCU $=$ Sideoats grama.

${ }_{7}^{6}$ MIDGR = Midgrasses.

${ }^{7}$ CSGR = Cool seasnn grasses

${ }^{\mathrm{abc}}$ Means within rows with different letter differed significantly $(P<0.05)$ 
Texas (Kothmann et al. 1978). Apparently the characteristics that serve curly-mesquite so well under intensive grazing are ineffective when grazing is removed.

\section{Other Shortgrasses}

Average shortgrass composition for all grazed treatments ranged from $28.5 \%$ in 1980 to $42 \%$ in 1985 and dropped to $8 \%$ in 1991. The trend was similar for all treatments. Change in shortgrass composition for the grazed treatments was not different from the ungrazed treatment $(P=0.15)$. Shortgrasses are probably less competitive for sunlight and nutrients than either curlymesquite or midgrasses and appear to respond to the combined increase or decrease of these other categories of grasses.

\section{Threeawn Species}

In 1980 , threeawn species averaged $12 \%$ of the grass composition, ranging from $8 \%$ in the $2.5 \mathrm{x}$ treatment to $17 \%$ in the $2.0 \mathrm{x}$ treatment. The livestock exclosure was $19 \%$. In 1985, threeawn species had decreased to an average of $5 \%$ for all stocking rate treatments. In 1991, threeawn species averaged $9 \%$, ranging from $18 \%$ of the grass composition in the exclosure to $2 \%$ for the $2.0 \mathrm{x}$ treatment. Threeawn species composition was stable for the exclosure and the 2 lighter stocked grazing treatments $(1.0 \mathrm{x}$ and $1.5 \mathrm{x}$ ) but decreased under the heavier stocked treatments. However, the percent change in threeawn composition for the grazed treatments compared to the ungrazed treatment was not different $(P=0.20)$. Threeawns generally are considered to have a low preference value (Taylor 1973). Forage demand exceeded forage production at the heavier stocking rates. Even marginally preferred plants were negatively impacted as the grazing intensity and frequency increased. The response of threeawns in the current study was as an increaser (Dyksterhuis 1949).

\section{Sideoats Grama}

Sideoats grama with a mean composition of $6 \%$ in 1980 , ranged from $4 \%$ to $9 \%$ for the grazing treatments and totaled $15 \%$ for the exclosure. By 1985, sideoats had decreased in all grazing treatments to a mean of $1 \%$.

Sideoats grama is a high seral grass in the western part of the Edwards Plateau and is considered a preferred forage for cattle, sheep, and goats (Ralphs et al. 1990, Taylor 1973, Robinson 1990). Sideoats grama is also considered a key management species and a good indicator of rangeland health. If management reduces sideoats and other midgrasses, infiltration rate decreases, erosion rate increases, and water storage capacity of the soil decreases (Thurow 1990). Erosion not only exports nutrients needed for forage production but also reduces the depth of the soil.

These results raise concern because sideoats is an important grass in this region. It does not appear to be possible to sustain sideoats grama with the frequency and the intensity of defoliation used in this grazing study $(P=0.01$; grazed compared to ungrazed). The significant increase of sideoats in the exclosure indicates that conditions were favorable for sideoats grama during the study period.

\section{Other Midgrasses}

Midgrasses responded to the treatments in a manner similar as sideoats grama. Initial midgrass composition ranged from $14 \%$ for the $1.0 x$ treatment to $20 \%$ for the $1.5 x$ treatment with a mean of $16 \%$ (Table 2). Midgrasses represented $3 \%$ of the grass composition for the exclosure. Midyrass composition for the stocking treatments decreased to $10 \%$ in 1985 and then decreased to $3 \%$ in 1991. Midgrass composition increased to $53 \%$ for the exclosure in 1991 and was greater $(P=0.01)$ than in the grazed treatments.

\section{Cool-season Grasses}

Cool-season grasses were represented mostly by Texas wintergrass. This was the only category which had a significant interaction $(P=0.06)$ between year and stocking rate. Percent composition of cool-season grasses decreased from 1981 to 1991 in all grazed treatments except the $1.0 x$ stocking rate (Table 2). Coolseason grasses also declined in the exclosure, $8 \%$ in 1981 to $2 \%$ in 1991. There was no difference $(P=0.35)$ in the percent change of cool-season grass composition between the grazed and ungrazed treatments. Distribution of precipitation may have had a greater influence on cool-season grasses than the experimental treatments. Most of the precipitation for the 10-year study occurred during the warm season.

\section{Conclusions}

Rotational stocking with 3-day graze periods and 51-day rest periods was not able to sustain initial species composition at any stocking rate tested. Curly-mesquite increased in all stocked treatments, while midgrasses and sideoats grama decreased. These results were predicted in 1985 and confirmed as the study was conducted for another 5 years. Because the midgrasses were palatable species and not abundant, they were defoliated too intensively and too frequently to remain in the community at previous levels. From this study, stocking rates at or above moderate stocking could not be recommended for rotational stocking with short periods of rest. However, previous research on the Sonora Research Station demonstrated that rotational stocking with longer rest periods (> 80 days) during the growing season did allow midgrasses to increase (Taylor et al. 1993a). Exclusion of livestock grazing resulted in midgrasses dominating the site.

\section{Management Implications}

Even though rotational stocking methods have been claimed to improve or maintain range condition, range managers must be alert when implementing rotational stocking on semi-arid rangelands. Increasing the density and production of preferred plants is a difficult and slow process. The presence of competing vegetation and the influence of precipitation, soil type, and intensity and frequency of grazing results in variable responses to stocking methods.

For rotational stocking to be successful, we recommend monitoring of grazing use on preferred plants. Range managers must then adjust both grazing methods and animal numbers to maintain proper use on key forage species. We also want to emphasize that these results may not apply to all locations; i.e., these management implications should be limited to locations with vegetation, soils, and environment that are similar to those represented in this study. 


\section{Literature Cited}

Anderson, D.M. and M.M. Kothmann. 1982. A two-step sampling technique for estimating standing crop of range vegetation. J. Range Manage. 35:675-677.

Dyksterhuis, E.J. 1949. Condition and management of rangeland based on quantitative ecology. J. Range Manage. 2:104-115.

Fuhlendorf, S.D. 1996. Multi-species vegetation responses to long-term herbivory and weather variation on the Edwards Plateau. Ph.D. Diss. Texas A\&M Univ., College Station, Tex.

Gould, F.W. 1975. The Grasses of Texas. Texas A\&M Univ. Press, College Station, Tex.

Heitschmidt, R.K. and C.A. Taylor, Jr. 1991. Livestock Production. In: Heitschmidt \& Stuth (eds) Grazing management: An ecological perspective. Timber Press Inc., Portland, Ore.

Holechek, J.L., R.D. Pieper, and C.H. Herbel. 1989. Range Management Principles and Practices. Prentice Hall, Englewood Cliffs, N.J.

Kinucan, R.J. 1987. Influence of soil seed bank, seed rain, inhibition competition and site disturbance on successional processes within three long-term grazing regimes on the Edwards Plateau, Texas. Ph.D. Diss., Texas A\&M Univ., College Station, Tex.

Kothmann, M.M. 1980. Integrating livestock needs to the grazing system. In: K.C. McDaniel and C.D. Allison (eds.) Proc. Grazing Manage. Syst. for S.W. Range Symp. New Mexico St., Univ., Las Cruces, N.M.

Kothmann, M.M., W.J. Waldrip, and G.W. Mathis. 1978. Rangeland vegetation of the Texas Rolling Plains: response to grazing management and weather. In: Proc. First Internat. Range. Congress., Soc. Range Manage. Denver, Colo.

Merrill, L.B. and V.A. Young. 1954. Results of grazing single classes of livestock in combination with several classes when stocking rates are constant. Tex. Agr. Exp. Sta. Prog. Rep. 1726.

Merrill, L.B. and V.A. Young. 1959. Response of curly-mesquite to height and frequency of clipping. Tex. Agr. Exp. Sta. MP-33.

Ralphs, M.H., M.M. Kothmann, and C.A. Taylor, Jr. 1990. Vegetation response to increased stocking rates in short-duration grazing. J. Range Manage. 43:104-108.

Robinson, C.L. 1990. Botanical and chemical composition of sheep diets on two grazing systems in the Edwards Plateau. M.S. Thesis, Texas A\&M Univ., College Station, Tex.

SAS. 1988. SAS/STAT User's guide (Release 6.03). SAS Institute Inc., Cary, N.C.

SCS. 1972. Soil Conservation Service Field Office Technical Guide. Edwards Plateau, Tex.

Smeins, F.E. and L.B. Merrill. 1988. Long-term change in a semiarid grassland. In: B. Amos and F. Gehlback (eds.). Edwards Plateau Vegetation: Plant Ecological Studies in Central Texas. Baylor Univ. Press, Waco, Tex.

Taylor, C.A., Jr. 1973. The botanical composition of cattle diets on a 7pasture high-intensity, low-frequency grazing system. M.S. Thesis, Texas A\&M Univ., College Station, Tex,

Taylor, C.A., Jr., M.M. Kothmann, L.B. Merrill, and D. Elledge. 1980. Diet selection by cattle under high-intensity, low-frequency short duration and Merrill grazing systems. J. Range Manage. 33:428.

Taylor, C.A., Jr., T.D. Brooks, and N.E. Garza. 1993a. Forage production from short duration and high-intensity, low-frequency grazing systerns. J. Range Manage. 46:118-121.

Taylor, C.A., Jr., N.E. Garza, and T.D. Brooks. 1993b. Grazing systems on the Edwards Plateau of Texas: Are they worth the trouble? I. Soil and vegetation response. Rangelands. 15:53-57.

Taylor, C.A., Jr., N.E. Garza, and T.D. Brooks. 1993c. Grazing systems on the Edwards Plateau of Texas: Are they worth the trouble? II. Livestock response. Rangelands. 15:58-60.

Thurow, T.L. 1990. The role of range management in determining the frequency and consequences of drought. Tex. Agr. Exp. Sta. TR-90-1.

Thurow, T.L., W.H. Blackburn, and C.A. Taylor, Jr. 1987. Rainfall interception by midgrass, shortgrass, and liveoak mottes. J. Range Manage. 40:455-460.
Thurow, T.L., W.H. Blackburn, and C.A. Taylor, Jr. 1988. Some vegetation responses to selected livestock grazing strategies, Edwards Plateau, Texas. J. Range Manage. 41:108-114.

Warren, S.D., W.H. Blackburn, and C.A. Taylor, Jr. 1986a. Effects of season and stage of rotation cycle on hydrologic condition of rangeland under intensive rotation grazing. J. Range Manage. 39:491-495.

Warren, S.D., W.H. Blackburn, and C.A. Taylor, Jr. 1986b. Soil hydrologic response to number of pastures and stocking density under intensive rotation grazing. J. Range Manage. 39:500-504. 


\section{Technical Comment}

Comment: Plant, small mammal, and avian diversity following control of honey mesquite, J. Range Manage. 50:205-212 by Roger Peterson, 1750 Camino Corrales, Santa Fe, N.M. 87505

Chances are 9 to 1 that your roof will collapse. Should you do something about it? No! according to Nolte and Fulbright (1997: Journal of Range Management 50:205-212). They reason that 9 to 1 odds are not at the level of scientific proof (usually taken to be 19 to 1 or, for some purposes, 99 to 1), therefore "it does not appear that your roof will fall." Or rather, in their terms, herbicide treatment "does not appear to negatively impact plant and vertebrate species richness and diversity..."

Nolte and Fulbright set out to test the hypothesis that herbicide application to kill honey mesquite would reduce plant and vertebrate species richness and diversity. They found that for plants and birds, species richness and Shannon's diversity index increased or stayed constant on untreated plots but decreased (usually decisively) or stayed constant (when the control figure was more than doubling) after treatment. By their analysis these decreases (or in one case, relative decrease) in diversity due to treatment did not attain to the 19 to 1 confidence level, even though they were all in the same, negative direction. They concluded that there appeared to be no negative affect of herbicide treatment. The correct conclusion (if their analysis were correct) would be that they had not proved that there was an effect; that is, they had not proved the roof would fall. That's different from proving it won't.

I and most reasonable people will act on 9 to 1 probabilities. Treatment mesquite under conditions of Nolte and Fulbright's experiment probably causes decreased diversity.

Response to Comment: Plant, small mammal, and avian diversity following control of honey mesquite by Tim Fulbright and Kenneth Nolte, Texas A\&M University Kingsville, Campus Box 218, Kingsville, Tex. 78363.

We wish to respond to Mr. Rober Peterson's critique of our article Plant, small mammal, and avian diversity following control of honey mesquite. Mr. Peterson stated" they reason that 9 to 1 odds are not at the level of scientific proof." We assume he is referring to our use of a significance level of 0.05 rather than 0.10 . Selection of a significance level is an arbitrary decision. We chose $\alpha=0.05$ to be conservative, i.e. to avoid type I errors. Most of the differences in our study were not large enough to be declared statistically significant at a significance level of 0.05 . We could have chosen $\alpha=0.10$. In 2 cases, post-treatment differences between controls and treatments could have been declared significant at the 0.10 level. But in other cases the $P$ values were larger.

Mr. Peterson stated that "decreases in diversity due to treatment did not attain to the 19 to 1 confidence level, even though they were all in the same negative direction." We reported 5 posttreatment species richness and Shannon's index comparisons in the paper. In 3 cases, species richness values were lower in the herbicide treatments (plants in 1992 and 1993 and birds) and in 2 cases species richness values were the same or greater in the herbicide treatments (small mammals in 1992 and 1993). Shannon's index was higher in the herbicide treatment in 1 of 5 cases. Beta diversity (vegetation patchiness) values were greater in herbicide treatments in 1992 and 1993. Thus, not all values in the herbicide treatments were in the "same negative direction."

We clearly pointed out the weakness of our study. Replication was limited, rainfall was above average during both years, and the study only lasted two years. Based on the results of our study, we believe one should be cautious in concluding that treating shrublands with herbicide does or does not reduce species diversity. Rather, our study was one case, with well above average rainfall and a fairly selective herbicide treatment in which statistically significant $(P<0.05)$ differences were not observed. Clearly, additional research in other ecosystems and climatic regimes is warranted and needed. Then we can collate the body of information available and search for patterns. 